життєдіяльність і соціальну активність особистості студентів можливий лише за умови функціонування міжособистісного простору, у якому кожен майбутній фахівець буде відчувати себе комфортно в емоційному плані та стабільно у плані саморозвитку. Навчально-виховний процес у вищих навчальних закладах I-II рівнів акредитації, які готують фахівців 3 освітньо-кваліфікаційним рівнем «молодший спеціаліст»- це передусім сталий, цілеспрямований процес створення інтерактивного соціокультурного середовища, що сприяє саморозвитку та самовихованню особистості, яка усвідомлює обрану професію невід’ємним складником універсального цивілізаційно-культурного простору. Саме це детермінує мету навчально-виховної діяльності у Фінансово-економічному коледжі Буковинського державного фінансовоекономічного університету, яка полягає у формуванні національної інтелігенції, оновленні і збагаченні духовного та інтелектуального генофонду нації, що передбачає гармонійно розвинену, цілісну особистість, фундаментальними характеристиками якої $€$ духовність, культурна самоідентифікація, соціальна i професійна компетентність у фінансово-економічній галузі.

\title{
Література
}

1. Бітаєв В. А. Людина і соціокультурне середовище: проблема взаємоадаптації / В. А. Бітаєв// Актуальні філософські та культурологічні проблеми сучасності (альманах). - К., 2000. - С. 81-90. 2. Давиденко А.Роль соціального середовища у творчості людини / А. Давиденко // Збірник наук. праць. - К., 2004. - С. 57-61. 3. Логвін В. Л. Розвиток соціокультурного середовища освітнього закладу в системі діяльності керівника школи / В. Л. Логвін //[Електронний ресурс]. - Режим доступу: http:/virtkafedra.ucoz.ua/elgurnal/pages/vyp7 /konf3/Logvin.pdf.4. Мануйлов Ю. С.

Средовой подход в воспитании / Ю. С. Мануйлов. - [2-е изд., перераб.]. М.: Н. Новгород, 2002. - 157 с. 5. Новикова Л. И. Школа и среда / Л. И. Новикова. М. : Знание, 1985. - 80 с. 6. Пащенко Д. І. Зарубіжний досвід гуманізації соціального середовища та виховання / Д. І. Пащенко. - К. : Знання, 1999. - 208 с. 7. Ясвин В. А. Образовательная среда: от моделирования к проектированию/В. А. Ясвин. - М. : Смысл, 2001. - 365 с.

УДК 378.016:004.42

Ірина Мінтій

\section{ФОРМИ ОРГАНІЗАЦІЇ НАВЧАННЯ ДЛЯ ФОРМУВАННЯ КОМПЕТЕНТНОСТЕЙ 3 ПРОГРАМУВАННЯ}

Мінтій I. C. Форми організації навчання для формування компетентностей 3 програмування.

У статті розглянуто загальні форми організації навчання (фронтальні, групові, парні й індивідуальні) та певні види занять (лекція, лабораторна робота, консультація) для формування в майбутніх учителів інформатики компетентностей 3 програмування на прикладі модуля «Вступ до програмування» шкільного курсу інформатики.

Ключові слова:компетентнісний підхід, форми організації навчання; фронтальні, парні, групові, індивідуальні форми; лекція, лабораторна робота, консультація, самостійна робота.

Минтий И. С. Формы организации обучения для формирования компетентностей в программировании.

В статье рассмотрены общие формы организации обучения (фронтальные, 
групповые, парные, индивидуальные) и определённые виды занятий (лекция, лабораторная работа, консультация) для формирования у будущих учителей информатики компетентностей в программировании на примере модуля «Введение в программирование» школьного курса информатики.

Ключевые слова: компетентностный подход, формы организации обучения; фронтальные, парные, групповые, индивидуальные формы; лекция, лабораторная работа, консультация, самостоятельная работа.

Mintiy I. S. Forms of training for the forming of competences in programming.

The article describes the basic forms of training (frontal, group, pair, individual) and certain kinds of activities (lecture, laboratory work, counseling) for the forming of competences in programming in future teachers of informatics on the example of «Introduction to Programming» module of the school course of computer science.

Key words:competence approach, forms of learning; frontal, pair, group and individual forms; lecture, laboratory work, counseling, independent work.

Упровадження компетентнісного підходу у вищу освіту зумовлює необхідність розроблення компетентнісно-орієнтованих методичних систем навчання студентів. Це питання розглядається у працях Т. Крамаренко, Т. Колчук, Т. Кобильника, С. Ракова, М. Рафальської, Л. Шевчук та ін.

У попередніх дослідженнях автора розглянуто окремі складники методичної системи формування у студентів педагогічних університетів компетентностей з програмування на основі функціонального підходу: цілі та зміст [5], засоби організації навчання [4].

Метою статmі $є$ розгляд форм організації навчання для формування у майбутніх учителів інформатики компетентностей з програмування.

Форма організації навчання - це обмежена в просторі та часі взаємозумовлена діяльність викладача й студента [2, с. 247].

Ураховуючи особливості комунікативної взаємодії між викладачем і студентами та між самими студентами, серед загальних форм організації навчання розглядають фронтальні (колективні), парні, індивідуальні та зі змінним складом студентів [6, с. 200].

Під час фронтального навчання всі студенти, присутні на занятті, працюють над одним і тим самим завданням в однаковому темпі. У шкільному курсі інформатики (підготовка студентів кваліфікацій «Фізик. Учитель фізики та астрономії. Учитель інформатики», «Математик. Учитель математики. Учитель інформатики», «Програміст прикладний, інженер-програміст. Учитель інформатики») під час вивчення модуля «Вступ до програмування» [5] для вступних тем на лабораторних заняттях здебільшого використовується саме ця форма організації навчання, оскільки рівень компетентностей 3 програмування у студентів $\epsilon$ переважно низьким (відбувається формування гносеологічного та праксеологічного складників).

Завдяки використанню комп'ютерно-орієнтованих засобів навчання (КОЗН), а саме електронної системи підтримки навчання (ЕСПН) Moodle, студенти з високим та достатнім рівнями гносеологічного та праксеологічного складників компетентностей 3 програмування мають можливість виконати завдання лабораторних робіт заздалегідь, тому на лабораторних заняттях викладач може залучити їх до навчання слабших студентів. Реалізація цієї форми знайшла своє відображення в методі учіння через навчання [6, с. 202], що сприяє формуванню ще й соціально-поведінкового складника компетентностей 3 програмування.

Під час навчання програмування ефективною $є$ парна форма організації 
навчання, за якої основна взаємодія відбувається між двома студентами, що працюють за одним робочим місцем, котрі можуть обговорювати завдання, здійснювати взаємонавчання або взаємоконтроль. Ця форма навчання $є$ переважною як під час лабораторних занять в аудиторії, так і в позааудиторний час.

Індивідуальна форма навчання передбачає виконання кожним студентом індивідуального завдання у власному темпі під керівництвом викладача.

Особливістю лабораторних занять в комп'ютерній аудиторії $є$ індивідуальний темп роботи кожного студента, навіть за фронтальної форми організації на початку заняття. В умовах комп'ютерного класу керувати індивідуальною діяльністю студентів досить складно: ситуація за кожним комп'ютером практично унікальна. У цьому випадку також доцільним буде використання методу учіння через навчання.

Ефективній організації індивідуальної роботи сприяє використання всіх можливостей КОЗН:

- елементів ЕСПН Moodle: індивідуальні завдання, тестові завдання, чат;

- системи Skype: чат, доступ до робочого столу, обмін файлами.

Під час роботи над проектами (остання тема розробленого модуля курсу) використовується групова форма організації навчання. Під час об'єднання студентів у групи варто враховувати їхнє бажання, але керівництво викладача $є$ необхідним. Групова форма роботи $є$ ефективною, якщо групи неоднорідні за рівнем предметних компетентностей, так і за пізнавальною активністю.

Використання КОЗН сприяє не лише індивідуалізації навчання, а й оптимізації групової роботи (за рахунок засобів для організації спільної роботи).

Зовнішні форми організації навчання інформатики позначають певний вид заняття: лекція, семінар, практичне заняття, лабораторне заняття, практикум, факультативне заняття, екзамен, предметні гуртки, студентські наукові співтовариства тощо.

У навчанні інформатики найпоширенішою $є$ лекційно-лабораторна форма [6, c. 201]. Згідно з робочою програмою на вивчення модуля «Вступ до програмування» передбачається 10 год. лекцій та 18 год. лабораторних занять. Також у модулі планується проведення консультацій та самостійна робота студентів.

Лекція - усне систематичне та послідовне подання матеріалу з певної проблеми, методу, теми, питання й тощо є провідною формою і методом навчання у ВН3 [6, c. 203]. Проведення лекцій 3 інформатики вимагає від лектора високого рівня методичних, психолого-педагогічних та інформатичних компетентностей.

Незважаючи на критику за пасивність навчання, лекція $\epsilon$ необхідною формою організації навчання зі студентами молодших курсів.

Підвищенню ефективності лекції сприяють використання наочних методів, проведення комп'ютерних презентацій, організація зворотнього зв'язку з аудиторією. Завданням лектора $\epsilon$ активізація мислительної діяльності та розвиток уваги студентів,організація на занятті атмосфери співтворчості та емоційної взаємодії [1, c. 107]. Перевагою лекції $\epsilon$ iï економічність: викладач подає матеріал за порівняно незначний час.

У зв'язку з упровадженням КОЗН (зокрема, ЕСПН Moodle, у якій у вигляді webсторінок розроблено лекції до курсу) функції лекції з інформаційної зміщуються в бік стимулювальної, виховної, розвивальної, орієнтовної, пояснювальної та переконувальної.

За метою проведення виокремлюють вступну, інформаційну та оглядову лекції.

Завданням вступної лекції курсу $\epsilon$ ознайомлення студентів 3 метою та призначенням курсу, його роллю та місцем у системі навчальних дисциплін. На лекції розглядаються й організаційні питання: загальна методика роботи над курсом (обсяг 
годин, форми організації навчання, самостійна робота); форми контролю, критерії оцінювання, навчально-методичний матеріал (підручники, електронні ресурси, освітні ресурси web). Також дається короткий історичний огляд курсу (етапи розвитку, імена відомих науковців) та перспективи розвитку науки і впровадження результатів іiі досягнень у практику. У вступній лекції важливо показати, яку роль у подальшому відіграватиме теоретичний матеріал 3 курсу як у навчальній, так і професійній діяльності. Вступна лекція сприяє професійній адаптації студентів молодших курсів.

Інформаційна лекція розкриває зміст теми відповідно до навчальної програми.

Оглядова лекція є підсумковою у вивченні теми або ж курсу загалом і сприяє систематизації знань. Оглядовою є остання лекція. На ній варто приділити увагу питанням, що викликають особливі труднощі у студентів, оголосити кількість балів, набраних кожним студентом протягом вивчення курсу.

Лабораторна робота (фронтальна) є основною формою роботи в комп'ютерному класі. Діяльність студентів може бути як синхронна, так і асинхронна. Досить часто відбувається швидке «розтікання» фронтальної діяльності навіть під час виконання спільного вихідного завдання. Роль викладача під час фронтальної лабораторної роботи - спостереження за роботою студентів (зокрема через мережу), надання їм оперативної допомоги [3, с. 58].

У розробленому курсі студенти мають можливість заздалегідь ознайомитися 3 завданнями лабораторних робіт (завдяки навчально-методичному комплексу «Вступ до програмування», розміщеному в ЕСПН Moodle).

Додаткові (консультаційні) форми організації навчання розраховані на окремих студентів або групу задля заповнення прогалин у знаннях, вироблення вмінь i навичок, задоволення підвищеного інтересу до навчального предмета. Так, на консультаціях можуть бути роз'яснені окремі питання, організоване повторне пояснення теми тощо.

Завдяки використанню КОЗН можливе проведення консультацій «на відстані»: використовуючи можливості ЕСПН Moodle (чат, форум); системи Skype (чат, надсилання файлів, аудіо- та відеоконференції). У навчанні програмування особливо цінною $\epsilon$ послуга системи Skype 3 надання доступу до робочого столу співрозмовника, що інтенсифікує процес надання допомоги студентам з розроблення та налагодження програми.

Самостійна робота - це спланована викладачем робота студентів, що виконується за його завданням і під його керівництвом, але без особистої участі викладача.

В організації самостійної роботи студентів можна виокремити кілька стадій:

1. Планування (здійснюється під час розроблення робочої програми). Визначаючи зміст та форми організації самостійної роботи, слід урахувати вимоги: відповідність меті і завданням курсу, доступність, конкретність та чіткість постановки завдань, систематичність, контроль, однозначність оцінювання.

Плануючи самостійну роботу студента, викладач зобов'язаний створити відповідні умови для iii виконання. Для цього потрібен підвищений рівень мотивації виконання тієї чи тієї роботи, чітке пояснення значення кожної в майбутній навчальній або професійній діяльності, оскільки студенти засвоюють лише те, чого хочуть навчитися [1, с. 24].

2. Виконання. У разі необхідності можливе проведення консультацій (як індивідуальних, так і групових). Завдяки КОЗН можливе проведення «заочних» консультацій.

3. Контроль та корекція. Перевірка виконання самостійної роботи дозволяє 
суттєво впливати на ії якість. Ефективність самостійної роботи студентів залежить не лише від вимог, що висуваються до їі виконання, але й від прийомів перевірки, які повинні бути різноманітними як за формою, так і за змістом. Головними вимогами до контролю за самостійною роботою є систематичність, своєчасність, об'єктивність, оперативність, дієвість, економічність. Можливості ЕСПН Moodle відповідають усім зазначеним вимогам: завдяки електронному журналу викладач має можливість отримати відомості про всіх зареєстрованих учасників курсу: вид роботи, кількість часу, витраченого на певний вид роботи, отримані результати.

Варто зауважити, що своєчасність, систематичність та якість виконання самостійної роботи є одним із показників сформованості ціннісно-мотиваційного складника компетентностей. Адже він свідчить про формування таких якостей, як наполегливість, уміння ставити цілі та знаходити шляхи їх досягнення; у разі необхідності - вносити зміни та діяти відповідно до зовнішніх обставин; прагнення досягнути успіху.

У модулі «Вступ до програмування» передбачаються такі види самостійної роботи: підготовка до лекцій (у тому числі - виступів на них), лабораторних робіт, заліку, виконання рефератів, виконання індивідуальних завдань та проектів.

Самостійна робота 3 названого модуля сприяє формуванню не лише компетентностей 3 програмування, а й навчальній компетентності: засвоєнню прийомів процесу пізнання; розвитку пізнавальних здібностей; умінь та навичок самостійного дослідження проблем; здатності до самостійного здобуття знань, тобто здатності до самонавчання; уміння користуватися джерелами i засобами різноманітних даних, повідомлень, постійно підвищувати рівень своєї освіти.

Використання КОЗН уможливлює ефективну реалізацію принципу неперервності навчання i відкритості змісту навчання, а також дає змогу реалізовувати самостійну навчальну діяльність студентів.

Самостійна навчальна діяльність студентів у розробленому навчальнометодичному комплексі здійснюється через опрацювання теоретичних відомостей 3 самоконтролем засвоєння навчального матеріалу; дослідницьку і пошукову діяльність (шляхом виконання індивідуальних завдань та проектів); участь в іграх (навчальних, розвивальних тощо); самотестування і тестування; залучення студентів до створення різноманітних елементів (глосаріїв, wiki, ігор тощо).

Отже, для формування всіх складників компетентностей із програмування доцільним $\epsilon$ педагогічно виважене гармонійне поєднання різноманітних форм організації навчання: на лекціях відбувається формування переважно гносеологічного та аксіологічного складників, на лабораторних заняттях - праксеологічного та соціально-комунікативного. Використання ж проектної форми сприяє формуванню праксеологічного, соціально-комунікативного та аксіологічного складників передусім i гносеологічного через самостійне опрацювання студентами необхідного теоретичного матеріалу.

\section{Література}

1. Кобильник Т. П. Методична система навчання математичної інформатики у педагогічному університеті : дис. ... канд. пед. наук : 13.00 .02 «Теорія та методика навчання (інформатика)»/ Кобильник Тарас Петрович; Національний педагогічний ун-т ім. М. П. Драгоманова. - К., 2009. - 256 с. 2. Кузьмінський А. І. Педагогіка вищої школи : [навч. посіб. для студ. вищ. навч. закладів] / А. І. Кузьмінський. - К. : Знання-Прес, 2005. - 485 с. З. Малев В. В. Общая методика преподавания информатики : [учеб. пособ.] / В. В. Малев. - Воронеж: ВГПУ, 2005.- 
271 c.4. Мінтій I. С. Засоби формування у студентів педагогічних університетів компетентності в програмуванні на основі функціонального підходу / I. С. Мінтій // Вісник Черкаського університету. Серія педагогічні науки. - Випуск 191. Частина I. Черкаси : Вид. від. ЧНУ ім. Б. Хмельницького, 2010. - С. 86-92. 5. Мінтій І. С. Навчально-методичне забезпечення курсу «Вступ до програмування» / I. С. Мінтій // Матеріали VIII Міжнародної науково-технічної конференції : Київ-Севастополь, 14 17 вересня 2010 р. - К. : Міністерство регіонального розвитку та будівництва України, 2010. - С. 113-114. 6. Семеріков С. О. Теоретико-методичні основи фундаменталізації навчання інформатичних дисциплін у вищих навчальних закладах : дис. ... доктора пед. наук : 13.00 .02 «Теорія та методика навчання (інформатика)»/ Семеріков Сергій Олексійович; Національний педагогічний ун-т ім. М. П. Драгоманова. - К., 2009. - 369 с.

\section{ФОРМУВАННЯ ПРОФЕСІЙНИХ ЗНАНЬ У МАЙБУТНІХ ПЕРЕКЛАДАЧІВ ТЕХНІЧНОЇ ЛІТЕРАТУРИ}

Пизіна Є. В. Формування професійних знань у майбутніх перекладачів технічної літератури.

У статті описано процес формування професійних знань у студентів ВТНЗ майбутніх перекладачів технічної літератури із застосуванням інформаційнокомунікаційних технологій. Автор наводить конкретні приклади використовуваних нею форм, методів і прийомів навчання й описує отримані протягом педагогічного експерименту результати.

Ключові слова:професійна підготовка, компетенції перекладача, технічна література, ВТНЗ, професійні знання, інформаційно-комунікаційні технології.

Пызина Е. В. Формирование профессиональных знаний у будущих переводчиков технической литературы.

В статье описывается процесс формирования профессиональных знаний у студентов ВТУЗ - будущих переводчиков технической литературы с использованием информационно-коммуникационных технологий. Автор приводит конкретные примеры используемых ею форм, методов и приемов обучения и описывает результаты, полученные в ходе педагогического эксперимента.

Ключевые слова: профессиональная подготовка, компетенции переводчика, техническая литература, ВТУЗ, профессиональные знания, информационнокоммуникационные технологии.

Pyzina E. V. Building professional knowledge of future technical translators.

The article discusses how its author built professional knowledge of future technical translators in the students of technical universities with the help of information technologies. The researcher both provides her readers with real examples of the learning forms, methods, and techniques used and describes the results she has obtained during the educational experiment.

Key words: professional training, translator's competencies, technical literature, technical university, professional knowledge, information technologies.

Здатність перекладача технічної літератури ефективно виконувати свої професійні та суспільні обов'язки як посередника у всесвітньому науково-технічному 